\title{
The Influence of Training and Development on Employee Retention: Empirical Evidence from Banking Industry in Tanzania
}

\author{
William Amos Pallangyo ${ }^{*}$, Amos Ephraim Hanai ${ }^{2}$ \\ ${ }^{1}$ Senior Lecturer-The law School of Tanzania, P.O. Box 9422 Dar es Salaam \\ ${ }^{2}$ Management Consultant- COSEP Company Ltd, P.O. Box 68376 Dar es Salaam
}

*Corresponding Author: William Amos Pallangyo, Senior Lecturer-The law School of Tanzania, P.O. Box 9422 Dar es Salaam

\begin{abstract}
This paper aims at exploring the influence of Training and Development (T\&D) on employee retention in the banking industry of Tanzania. A stratified sampling technique was used to ensure representativeness of the sample, eleven banks were selected purposely and a simple random sampling was applied to draw a sample of 370 employees. Binary logistic regression analysis was used to analyze quantitative data. The results revealed a ' $p$ ' value of 0.001 that indicate that T\&D was significantly influencing employee retention. The study concluded that $T \& D$ attributes (career planning and growth opportunities) have significant influence on employee retention at the banks. The study recommends retention policies which are reflecting career planning and growth opportunities as T\&D attributes that were valued most by employees.
\end{abstract}

Keywords: Employee retention, Training and Development, Bank

\section{INTRODUCTION}

Recently, employee retention has become a serious concern in many organizations (Mehrez and Bakri, 2019). Thirupathy and Dhayalan (2016) argued that today's business environment is very competitive thus making skilled employees the major differentiating factor.The study admitted that organizations in these days rely on the expertise of their employees in order to compete and gain competitive advantage in the market. Samuel and Chipunza (2009) emphasized that retention of skilled employees is vital for sustaining competition as well as in increasing effective and efficient service delivery in the organizations. In the same perspective, Ibidunni, et al. (2016) argued that employee retention helps in improving organizational performance. Conclusively, employee retention is now regarded as vital for organizational performance as well as competitiveness.

The liberalization of the economy in Tanzania in 1980s and financial sector reforms in 1990s allowed private banks to operate in the country. The economic liberation and financial reforms also resulted into increased number of banks. Prior to economic liberalization, Tanzania had four banks but by 2017 the number had raised to fifty eight banks (BOT, 2017). This resultedin existence of competitive business environment and dynamic market in the banking industry. The banks started experiencing a problem in retaining employees especially reputable ones (Mboya, 2012; Kweka and Sedoyeka, 2014).Recognizing the importance of employee retention and its benefits, many banks took initiatives in order to improve employee retention (Rashidi and Rahman, 2013; Msisiri and Juma, 2017). Banking institutions in Tanzania have adopted different employee retention strategies and initiatives.

Despite clear evidence on the benefits of employee retention from the empirical literature and initiatives taken, still there is a problem of retaining desirable employees.Shahin (2017) admitted that poor employee retention can lead to many operational problems, decreasing morale, low productivity and increase in cost to the organization. Probably, the development and implementation of retention strategies had limited understanding of the key factors in the Tanzanian context.Oyagi and Kembu (2014) argued that poor retention of employees imposes costs of recruitment, training new employees and additional burden of work on remaining employees. Given this situation, it is important to 
understand what factors influence employee retention in Tanzanian banks. The existing literature has revealed many employee retention factors but this study intends to explore the T\&D influence on the employee retention in the Tanzanian banks.

Msisiri and Juma (2017) found that continuous improvement to employees influenced employee retention at CRDB bank in Arusha, Tanzania. Oyagi and Kembu (2014) also studied employee retention in the banking sector and indicated that promotion opportunities had significant influence. However, studies had come with conflicting findings. For example, Umamaheswari and Krishnan (2016) found insignificant influence of $T \& D$ on employee retention, while, Rashid and Rahman (2013) indicated a significant influence of T\&D on employee retention.

Given the conflicting findings in the literature and the problem of retaining employees which affect the banking performance negatively, it is not clear whetherT\&D can help to influence employee retention. Therefore, this paper aimed at filling the gap by investigating the influence of T\&D on employee retention in the banking industry.

\subsection{Training and Development and Employee Retention}

Several scholars defined the concept of employee retention to fit their context of study. The paper adopts the definition introduced by Gayathri, et al. (2012) who defined employee retention as a process in which employees are encouraged to stay with the organization for the maximum period of time or until the completion of the project. Msengeti and Obwogi (2015) defined employee retention as the efforts to develop strategies and initiatives that support current staff into remaining with the organization. Regina and Rosalia (2015) evidenced that there was no single factor for employee retention. According to Francis (2014) T\&D refers to the formal activities undertaken by an organization to help employees acquire the skills and experience needed to perform current or future jobs.

Herzberg two factor theory of 1966 provided a theoretical background for this study. The theory suggests that there are certain factors in the workplace that cause job satisfaction (and motivation) whiles others cause dissatisfaction. According to Herzberg (1966) two factor theory, motivation of employees at workplace can occur as a result of the use of motivators such as achievement, responsibility, the work itself, recognition, advancement and growth. Whereas hygiene factors such as company policy and administration, interpersonal relations, salary, supervision, job security and working conditions, would not motivate or create satisfaction to employees but instead it would result in a neutral state. Despite that Herzberg two factor theory is a motivation theory which was developed to study employee motivation, but in this study the theory was considered relevant on studying employee retention as it has been empirically evidenced (Motlou and Karodia, 2016; Waweru and Kagiri, 2018) that when employees are motivated or satisfied at work they are likely to stay in the organization.

The Applicability of Herzberg (1966) two factor theory in studying employee retention have been observed and evidenced in a number of empirical studies (Msengeti and Obwogi, 2015; Thirupathy and Dhayalan, 2016). For instance, Kassa (2015) used Herzberg two factor theory to study employee retention and found a positive and significant relationship between motivational factors such as recognition, promotion and development on employee retention. In related perspective, Adzei and Atinga (2012) linked motivation and retention of health workers in Ghana's district hospitals. Thirupathy and Dhayalan (2016) on studying employee retention in India indicated that T\&D is among the motivational variables that significantly influenced employee retention. This finding is similar to the results of Mehrez and Bakri (2019) who indicated a relationship between T\&D with employee retention in emerging economies in Qatar. Nyambura and Kamara (2017) did a study on employee retention in public universities in Kenyaand revealed a positive and significant relationship between T\&D and employee retention.Despite that many empirical studies (Ldama and Bazza, 2015; Mathimaran and Kumar, 2017) evidenced the significant relationship between T\&D with employee retention but some studies indicated contrary findings. For example, Umamaheswari and Krishnan (2016) who conducted a study on employee retention in India found insignificant relationship between $\mathrm{T} \& \mathrm{D}$ and employee retention.

On the other hand, Imna and Hassan (2015) found that career development has a positive and significant impact on employee retention in Maldives retail industry. In a Pakistani an banking 
context, Ahmada, et al. (2015) did a study on human resource practices and employee retention found that training opportunities was one of the most important strategies in retaining employees. However, Terera and Ngirande (2014) revealed insignificant relationship between training and employee retention. Sohail, et al. (2011) in studying employee retention at the textile sector in Pakistan indicated that there was strong positive correlation between career path and employee retention. Similarly, Nasir and Mahmood (2016) revealed a significant relation of career development with employee retention when studying determinants of employee retention in Pakistan.

Salman, et al. (2014) carried out a study on factors affecting employee retention at the banking sector in Pakistan and found that promotion opportunities, education/training opportunities and growth opportunities have influence on employee retention. On the other hand, Francis (2014) who found a significant relationship between $T \& D$ and employee retention in Nigeria's manufacturing industries used opportunities to upgrade knowledge and skills, opportunities to improve performance, job related training and opportunity for professional development. In related perspective, Hong, et al. (2012) studied the effect of T\&D on employee retention used attributes such as opportunities for higher qualification, training on job skills, training on quality improvement skills, mentoring and career planning to measure training and development. In the African context, Mutiria, et al. (2015) argued that training and career growth have significant influence on employee retention at Meru University of Science and Technology in Kenya.

In Tanzania, Msisiri and Juma (2017) did a study on the relationship between non-financial rewards and retention of employees in the banking industry in Arusha and used regression analysis found that continuous improvement to employees had positive influence on employee retention. Muhoho (2014) in studying factors influencing employee retention in Tanzania's work organizations indicated that opportunities for further development strongly influenced retention of employees.

Most prior studies as cited above have indicated the relationship between T\&D with employee retention. However, different results from previous studies on the attributes of training and development which influenced employee retention may be due to the fact that satisfaction level, sensitivity level, perceptions, attitudes, behaviours and needs of every individual are different (Zareen et al., 2013). This may imply that more research is needed in different organizational settings in finding out specific training and development attributes that can influence employee retention on those settings. This may also raise a need for investigating further the needs and perceptions of employees with respect to training and development that can influence retention since they are not the same.

\subsection{Conceptual Framework}

The study developed the conceptual framework based on the discussion of the literature review above. One dependent variable namely Employee Retention (ER) and one independent variable namely Training and Development (T\&D) were used to develop a conceptual framework as described in figure 1.

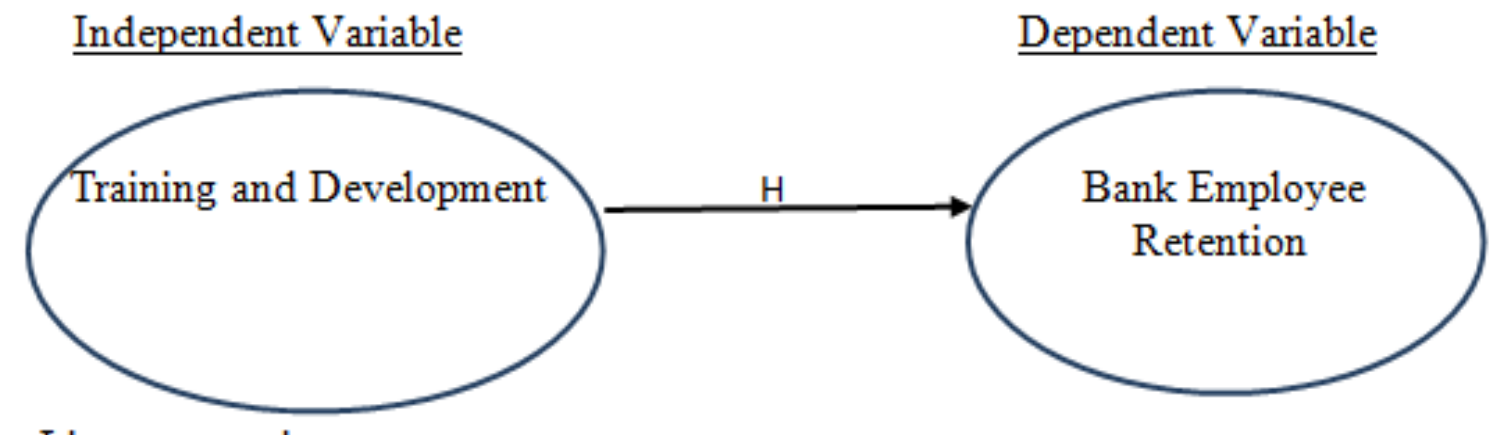

Figure1.0. Conceptual framework

Source: Literature review

\section{RESEARCH METHODOLOGY}

The Quantitative method was used in this study and the positivism philosophical stance was adopted. This is because the developed hypothesis and proposed model can be tested to explain the influence of 
T\&Don employee retention among banking institutions. According to Lancaster (2005) positivism philosophy assumes that the researcher is independent, concentrates on facts by testing hypothesis and there are no human interests on the study.Thestudy used the survey strategy and employed explanatory research design which helped to test the existence of relationships among variables and validated a model which can be used to explain employee retention in aspects of training and development in the context of banking institutions in Dar es salaam, Tanzania. The rationale to use explanatory design was based on its usefulness in explaining causal relationship among variables and to produce a model for these relationships.

Data was collected in Dar es Salaam region. The study area was selected because most of the banking institutions are operating in Dar es Salaam region than any other region in the country and this resulted high competition which in turn influences competition in retaining skilled bankers. Stratified sampling was used to ensure representativeness of banks basing on their bank categories such as commercial banks, community banks, financial institutions, development finance institutions and microfinance banks. Thereafter eleven banks were selected purposively and then simple random sampling was used to draw a sample of 370 employees from the selected banks that were given questionnaires. The overall sample size was allocated proportionally among the eleven banks depending on their number of employees.

The pilot study was conducted before the main survey to ensure the suitability of data collection instrument. Data analysis was done using both descriptive and inferential analysis. Binary logistic regression analysis was used to test a hypothesis and to develop a model on training and development that can explain employee retention among banking institutions in Dar es Salaam. IBM SPSS 23software was applied to support the analysis in the study.

\subsection{Findings}

\subsubsection{Employee's Characteristics}

The employee's characteristics were profiled based on their gender, marital status, age, education level, management level and years worked in the organization as described in Table $\mathbf{1 .}$

Table1. Employee's Characteristics

\begin{tabular}{|c|c|c|c|}
\hline Characteristics & & Frequency & Percentage \\
\hline \multirow{2}{*}{ Gender } & \multirow{2}{*}{$\begin{array}{l}\text { Male } \\
\text { Female }\end{array}$} & 134 & 41.1 \\
\hline & & 192 & 58.9 \\
\hline \multirow[t]{4}{*}{ Marital status } & \multirow{4}{*}{$\begin{array}{l}\text { Married } \\
\text { Single } \\
\text { Widow } \\
\text { Divorced/Separated }\end{array}$} & 188 & 57.7 \\
\hline & & 124 & 38 \\
\hline & & 7 & 2.1 \\
\hline & & 7 & 2.1 \\
\hline \multirow[t]{4}{*}{ Age } & \multirow{4}{*}{$\begin{array}{l}20-30 \text { years } \\
30-40 \text { years } \\
40-50 \text { years } \\
50-60 \text { years }\end{array}$} & 100 & 30.7 \\
\hline & & 158 & 48.5 \\
\hline & & 48 & 14.7 \\
\hline & & 20 & 6.1 \\
\hline \multirow[t]{4}{*}{ Education level } & \multirow{4}{*}{$\begin{array}{l}\text { Secondary } \\
\text { Non-degree } \\
\text { Bachelor } \\
\text { Postgraduate }\end{array}$} & 6 & 1.8 \\
\hline & & 15 & 4.6 \\
\hline & & 217 & 66.6 \\
\hline & & 88 & 27 \\
\hline \multirow[t]{4}{*}{ Years worked } & \multirow{4}{*}{$\begin{array}{l}\text { Less than } 1 \text { year } \\
1 \text { to less than } 5 \text { years } \\
5 \text { to less than } 10 \text { years } \\
\text { Above } 10 \text { years }\end{array}$} & 17 & 5.2 \\
\hline & & 153 & 46.9 \\
\hline & & 96 & 29.4 \\
\hline & & 60 & 18.4 \\
\hline \multirow[t]{3}{*}{ Management level } & \multirow{3}{*}{$\begin{array}{l}\text { Non-management } \\
\text { Mid-level management } \\
\text { Top management }\end{array}$} & 197 & 60.4 \\
\hline & & 121 & 37.1 \\
\hline & & 8 & 2.5 \\
\hline Total & & 326 & 100 \\
\hline
\end{tabular}

Based on the findings in table 1, it is implied that at least there was representativeness of the sample in terms of each unique employee characteristic. The findings on gender of the respondents indicated that female respondents were slightly higher than male respondents as among the 326 respondents 
contacted, $41.1 \%$ were male and $58.9 \%$ were female. This proportional of the percentage showed that there was representation of gender in the study as the data captured each group of gender. The study results on age revealed that majority of the respondents are in the age between 20 to 40 . The age group of 326 respondents of the study were as follows; $30.7 \%$ were aged between 20 - 30 years, $48.5 \%$ were aged between 30 - 40 years, $14.7 \%$ were aged between 40 - 50 years and $6.1 \%$ were aged between 50 - 60 years.

The study findings on the level of education of the respondents contacted indicated that the majority $(66.6 \%)$ were bachelor degree holders, $(27 \%)$ were postgraduate degree holders, $(4.6 \%)$ were nondegree holders while a few (1.8\%) were secondary education holders. This implies that the majority of the respondents involved had good level of education to handle bank operations and support customers and that each level of education background was captured. It was revealed that between the 326 respondents, $57.7 \%$ were married, $38 \%$ were single, $2.1 \%$ were widow and $2.1 \%$ were divorced/separated. Majority of respondents were married and single, however the proportional of the percentage indicated representation of marital status in the data collected and that each group of marital status was addressed.

The study findings on management level of respondents indicated that majority $(60.4 \%)$ were nonmanagement employees, $(37.1 \%)$ were mid-level management employees while a few $(2.5 \%)$ were top management employees. Therefore, at least each level of management was contacted in the study and data covered each management level as it was considered that each level may have different needs or perceptions that influence their decision to stay (Uitzinger, et al., 2016). The study results revealed that out of 326 respondents, 5.2\% have worked less than 1 year, $46.9 \%$ have worked 1 to less than 5 years, $29.4 \%$ have worked 5 to less than 10 years and $18.4 \%$ have worked above 10 years. This shows that the data covered each group category as the study considered that the number of years an employee has worked may have influence on their decision to stay as argued by (Agyeman and Ponniah, 2014).

\subsection{Validity and Reliability}

The study considered validity and reliability issues as these are important in testing the trustworthiness of the measurement instrument used in any research (Ihantola and Kihn, 2011). Content validity, construct validity and criterion validity were observed in this study as many scholars have used these kinds of validity in ensuring validity is achieved (Drost, 2011). A pilot study of survey instrument was done in order to ensure that the items in the questionnaire accurately reflect the theoretical domain of the latent construct it claims to measure. This involved few experts in human resource particularly in training and development area and few respondents as a sample population to help the study to strengthen the data collection instrument by assessing its coverage in theoretical domain.

To ensure construct validity the study identified correct operational measures for the T\&D construct. Furthermore, the study ensured that criterion validity was achieved by making sure that the data collection instrument was drawn and developed by considering strong validated literature and expert panels. Kimberlin and winter stein (2008) argue that criterion validity provides evidence about how well scores on the new measure correlate with other measures of the same construct or very similar underlying constructs that theoretically should be related.

Reliability issues were considered in this study by first ensuring that the data collection instrument was suitable to respondents and second assessing the internal consistency of the scale using Cronbach's Alpha. The study ensured that the language used in the questionnaire was clear to the respondents and hence the data collection instrument was suitable to them. A reliability analysis on the training and development scale comprising five items showed that the questionnaire attained an acceptable reliability with Alpha coefficient $(\alpha)$ equal to 0.882 as indicated in table 2.0 below. The obtained Alpha was within the acceptable range as it was between 0.7 and 0.9 as suggested by Streiner (2003). Streiner (2003) recommended a maximum value of Alpha coefficient $(\alpha)$ of 0.9 as when it is above that it can be too high and point to redundancy among the items.

Table2. Reliability Statistics

\begin{tabular}{|l|l|l|}
\hline Cronbach's Alpha & Cronbach's Alpha Based on Standardized Items & N of Items \\
\hline .882 & .883 & 5 \\
\hline
\end{tabular}


The Influence of Training and Development on Employee Retention: Empirical Evidence from Banking Industry in Tanzania

Furthermore, it was checked if Alpha coefficient could increase by removing some items in the questionnaire. The study retained all items as any deletion of an item would have resulted in a decrease in the Alpha coefficient. This is as postulated in the last column in table 3.0 below.

Table3. Item-Total Statistics

\begin{tabular}{|l|l|l|l|l|l|}
\hline & $\begin{array}{l}\text { Scale Mean if Item } \\
\text { Deleted }\end{array}$ & $\begin{array}{l}\text { Scale Variance if } \\
\text { Item Deleted }\end{array}$ & $\begin{array}{l}\text { Corrected Item- } \\
\text { Total Correlation }\end{array}$ & $\begin{array}{l}\text { Squared Multiple } \\
\text { Correlation }\end{array}$ & $\begin{array}{l}\text { Cronbach's Alpha if } \\
\text { Item Deleted }\end{array}$ \\
\hline TD1 & 14.13 & 14.515 & .668 & .449 & .869 \\
\hline TD2 & 13.77 & 13.945 & .714 & .514 & .858 \\
\hline TD4 & 13.87 & 15.046 & .673 & .456 & .867 \\
\hline TD5 & 13.86 & 13.744 & .784 & .643 & .841 \\
\hline TD6 & 13.90 & 14.174 & .752 & .606 & .849 \\
\hline
\end{tabular}

Key Note: TD1 $=$ Career planning, TD2 $=$ Growth, TD4 $=$ Coaching, TD5 $=$ Advancement, TD6 $=$ Improve performance

\subsection{Hypothesis Testing}

The objective of this paper was to test the hypothesis which state; Training and development have significant influence on employee retention at the banking industry in Dar es Salaam. Findings using binary logistic regression are as presented in the following tables.

Table4. Variables in the Equation

\begin{tabular}{|l|l|l|l|l|l|l|l|}
\hline \multicolumn{2}{|l|}{} & B & S.E. & Wald & Df & Sig. & Exp(B) \\
\hline Step 0 & Constant & -.360 & .113 & 10.209 & 1 & .001 & .698 \\
\hline
\end{tabular}

The results in table 4.0 above indicate a significant value (p) of 0.001 which is less than 0.05 implying that the predictor (training and development) makes a significant contribution in predicting the dependent variable employee retention.

In addition, the statistical significance of the indicators of training and development were also presented in table 5 .

Table5. Variables in the Equation

\begin{tabular}{|c|c|c|c|c|c|c|c|c|c|}
\hline & \multirow[t]{2}{*}{ B } & \multirow[t]{2}{*}{ S.E. } & \multirow[t]{2}{*}{ Wald } & \multirow[t]{2}{*}{ Df } & \multirow[t]{2}{*}{ Sig. } & \multirow[t]{2}{*}{$\operatorname{Exp}(B)$} & \multicolumn{2}{|c|}{ 95\% C.I.for EXP(B) } \\
\hline & & & & & & & & Lower & Upper \\
\hline \multirow{6}{*}{$\begin{array}{c}\text { Step } \\
1^{\mathrm{a}}\end{array}$} & TD1 & -.330 & .147 & 5.074 & 1 & .024 & .719 & .539 & .958 \\
\hline & TD2 & -.587 & .155 & 14.421 & 1 & .000 & .556 & .411 & .753 \\
\hline & TD4 & -.094 & .166 & .319 & 1 & .572 & .911 & .658 & 1.261 \\
\hline & TD5 & .079 & .185 & .182 & 1 & .670 & 1.082 & .753 & 1.556 \\
\hline & TD6 & -.246 & .183 & 1.803 & 1 & .179 & .782 & .546 & 1.120 \\
\hline & Constant & 3.705 & .592 & 39.191 & 1 & .000 & 40.647 & & \\
\hline
\end{tabular}

Key Note: TD1 $=$ Career planning, TD2 $=$ Growth, TD4 = Coaching, TD5 = Advancement, TD6 = Improve performance

The results provided in table 5 indicated that only two indicators, that is, TD1 (career planning) and TD2 (growth opportunities) were statistically significant. From the results you can see that three indicators known as TD4 $(\mathrm{p}=.572)$, TD5 $(\mathrm{p}=.670)$ and TD6 $(\mathrm{p}=.179)$ did not add significantly to the model whereas TD1 $(\mathrm{p}=.024)$ and TD2 $(\mathrm{p}=.000)$ added significantly to the model/prediction.

Therefore, the hypothesis which state that training and development have significant influence on employee retention at the banking industry in Dar es Salaam is confirmed. These results agree with other findings (Ldama and Bazza, 2015) that revealed a significant influence of training and development on employee retention in selected banking institutions in Nigeria. The hypothetical model derived from the findings is as shown in figure 2.0.

In the derived model, insignificant attributes (indicators) of training and development basing on $\mathrm{p}$ value were included in the model. This was due to the fact that employees are not the same as they have different levels of sensitivity, satisfaction levels, altitudes, behaviours and perceptions (Zareen et al., 2013) so even the insignificant attributes can have influence on employee retention as some 
employees are very sensitive. These results are aligned with Babyak (2004) who contend that nonsignificant values based on p-value alone does not mean no effect and that insignificant values can be important for example, in clinical decision making of whether to intervene or not to intervene a public health problem, and on deciding which parameters are important.

In addition, Wald Chi-Squared Test for the insignificant attributes was not zero as shown in table 4.0, this indicated that each insignificant attribute had some contribution to the model despite its smallness (Agresti, 1990, 2013). So, deleting insignificant indicator variables in the model would have resulted over fitting and hence an over fitted model as it has been argued by Harrell Jr and Slaughter (2008). Babyak (2004) also indicated that over fitting yields overly optimistic model results and the findings from the over fitted model do not really exist in the population and hence can't be replicated.

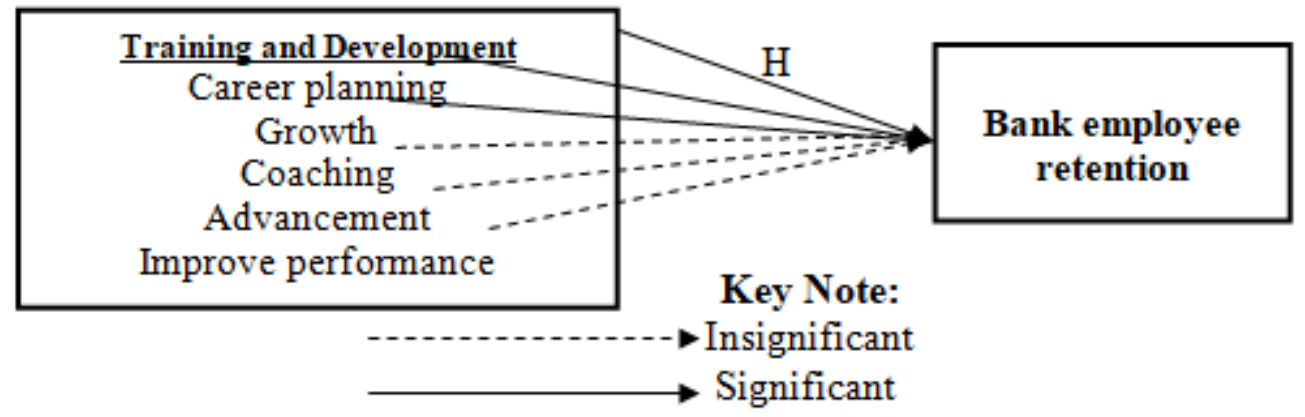

Figure2. Hypothetical Model for the Study

\subsection{Findings Discussion}

The influence of $T \&$ Don employee retention among banking institutions have been confirmed in prior retention studies (Ldama and Bazza, 2015; Ahmada, et al., 2015). Thus, employees at the banking institutions can be influenced by training and development. The paper developed one hypothesis that T\&Dhave significant influence on employee retention at the banking industry in Dar es Salaam. Findings from binary logistic regression analysis revealed a significant p-value of 0.001 which confirm that there is a significant relationship between T\&Dand employee retention. Prior studies (Nyambura and Kamara, 2017;Mathimaran and Kumar, 2017) have supported these results by reporting a significant relationship between training and development and employee retention. So, the support from empirical studies has provided evidence of what the current study confirmed through survey data.

Furthermore, the findings also indicated that the elements namely career planning, growth, coaching, advancement and opportunities to improve performance of T\&Dare strongly influencing employee retention at the banking industry in Dar es Salaam. Previous studies, Hong et al. 2012 revealed similar results thatT\&Dsuch as career planning; higher qualification, quality improvement, sufficient training and regular training have significant influence on employee retention. Fransis (2014) pointed out that there is a strong link between T\&Delements (such as opportunities to improve performance, opportunities to upgrade knowledge and skills, professional development and necessary training) with employee retention. The previous studies and the current study both indicated a strong relationship between training and development elements and employee retention. Despite of the similarities in the findings of this study and previous studies, the results differ in some of the elements of training and development.

For instance, Salman, et al. (2014) argued that promotion, education/training opportunities, growth opportunities, opportunities for training, sufficient time and budget for training and experienced trainers as important elements of training and development that significantly contributed on employee retention while this study couldn't find any support for experienced trainers, promotion, sufficient time and budget for training. The observed differences on the elements of training and development in influencing employee retention may have implication that not all elements are fulfilling and applicable in all contexts. This can be because of the influence of context on the outcome of research (Øvretveit, 2011).

This aligned with the results by Umamaheswari and Krishnan (2016) which revealed an insignificant relationship between training and development and employee retention. The study alsoconcluded that 
adoption of retention strategies by an organization with intention to improve employee retention can sometimes lead to insignificant influence on retention. This can imply that the prediction of training and development on employee retention may likely become insignificant if the elements do not cover the needs of employees that would influence their decision to stay. In addition, Zareen et al. (2013) argued that the needs and perceptions of employees are not the same and employees themselves are different as some of them strive for monetary rewards while others desire for authority and involvement in decision making process. This implies that it is important for the management to find out what attributes of training and development are valued most by employees in an organization that can be adopted to influence employee retention.

While the study results make clear that $T \& D$ is the base for improving employee retention in the banking industry in Dar es Salaam region, it also revealed that not all attributes are rewarding. This means that despite that coaching, career planning, growth opportunities, opportunities to improve performance and advancement are all together explaining the significant influence of training and development on employee retention in this study, but only two elements namely career planning and growth opportunities were statistically significant with $\mathrm{p}$ value of 0.024 and 0.000 respectively.

The empirical results in this paper indicated that career planning is significantly related to employee retention in the banking industry in Dar es Salaam. The results of this paper aligned with Kaur (2015) who revealed that career planning was among the critical variables that influenced employee retention. Rakhra (2018) who did a study on factors influencing employee retention in India also found that career planning contributed significantly on employee retention.

Despite many scholars (Kigo and Gachunga, 2016;Rakhra, 2018) as well as this paper argued that career planning contributes significantly on employee retention, Chew and Girardi (2012) came up with a contrary finding that career planning has no influence on employee retention. This may mean that career planning cannot be taken for granted by management that it can retain employees because it may not be applicable in other contexts. It is therefore crucial to find out what retention strategies are valued most by employees in their context so as to use them to influence retention of employees. On the other hand, this may also have implication that even if there is career management policy in place to ensure career path to employees but if the policy is not practiced by management it may not help to influence employee retention.

Previous studies (Alagusundaram and Raghavan, 2017; Palwasha, et al., 2017) as well as this paperargued that opportunities for growth contributed significantly on employee retention. In Tanzanian context, Muhoho (2014) revealed similar finding that opportunities for employee development strongly influencedretention of employees. Basing on results of the previous scholars and this paper it can be suggested that adequate growth opportunities to employees at the banking institutions in Dar es Salaam can significantly contribute on employee retention. These findings imply that the significance of training and development is simply contributed by career planning and growth opportunities as these were marked as strong retention strategies that helped to increase retention of employees among banks in Dar es Salaam. Therefore, the independent variable training and development and its attributes had significant contribution to bank employee retention.

\section{CONCLUSION AND RECOMMENDATION}

The paper tested the hypothesis on the influence of training and development on employee retention in the banking industry in Dar es Salaamand developed a model that can be used to explain employee retention specifically on training and development aspects. Grounded on employee retention literature, the study borrowed a factor (construct) from Herzberg (1966) dual factor theorytostudy employee retentionin the banking industry.This study confirmed thattraining and development has significant influence on employee retention at the banking industry in Dar es Salaam. The results from this paper can help bank managers in managing retention of employees especially on aspects of training and development. Moreover, the study pointed out further that career planning and growth opportunities were the most important attributes due to their significance influence, hence, can help in the development and implementation of training and development policies to enhance employee retention.

This study was done in Dar es Salaam region only in Tanzania. In future, additional research on the influence of $T \& D$ on employee retention is needed to be conducted in other regions of Tanzania. 
Also, the use of other methods such as multiple regression, Structural Equation Modeling and multinomial logistic regression can be applied in future to study employee retention.

\section{REFERENCES}

[1] Adzei, F.A. and Atinga R.A. (2012). "Motivation and retention of health workers in Ghana's district hospitals: Addressing the critical issues". Journal of health organization and management. 26(4): 467 485 .

[2] Agresti, A. (1990). Categorical Data Analysis. John Wiley and Sons. New York.

[3] Agresti, A. (2013). Categorical Data Analysis (3rd Ed). John Wiley \& Sons Inc. Hoboken.

[4] Ahmada, N., Tariqb, M.S. and Hussain, A. (2015). Human resource practices and employee retention, evidences from banking sector of Pakistan. Journal of Business and Management Research. 7:186 - 188.

[5] Alagusundaram, M. and Raghavan, S. (2017). Organisational Practices, Individual Characteristics and Employee Retention in the Energy Industry in Malaysia. International Journal of Innovative Research \& Development. 6(4):

[6] Babyak, M.A. (2004). What you see may not be what you get: a brief, nontechnical introduction to over fitting in regression-type models. Psychosomatic Medicine. 66: 411- 421.

[7] BoT (2017). Directorate of banking supervision Annual Report. Government Printer, Dar es Salaam, Tanzania.[https://www.bot-tz.org/BankingSupervision/BankingSupervision.asp] site visited on 20/01/2019.

[8] Chew, J. and Girardi, A. (2012). Is Career Management the Panacea to Retaining Vital Staff? International Journal of Management and Markerting Research. 1(1): 83 - 98.

[9] Clark, L.A. and Watson, D. (1995). Constructing validity: Basic issues in objective scale development. Psychological Assessment. 7(3): 309 - 319.

[10] Drost, E.A. (2011). Validity and Reliability in Social Science Research. Education Research and Perspectives. 38(1): 105 - 124.

[11] Francis, A.U. (2014). Human Resource Management Practices and Employee retention in Nigeria's manufacturing industries. International Journal of Scientific \& Engineering Research. 5(2): 1741 - 1754.

[12] Gayathri, R., Sivaraman, G. and Kamalambal, R. (2012).Employee retention strategies in BPO's - An empirical investigation. Interdisciplinary Journal of Contemporary Research in Business. 3(12): 572 - 583.

[13] Harrell Jr, F.E and Slaughter, J.C. (2008). Introduction to Biostatistics for Biomedical Research. [http://biostat.mc.vanderbilt.edu/wiki/pub/Main/ClinStat/ci2.biostat1.pdf] site visited on 22/09/2019.

[14] Herzberg, F. (1966).Work and the nature of man. Thomas Y. Crowell Company. New York.

[15] Hong, E.N., Hao, L.Z., Kumar, R., Ramendran, C. and Kadiresan, V. (2012). An effectiveness of human resource management practices on employee retention in institute of higher learning: - a regression analysis. International Journal of Business Research and Management. 3(2): 60 - 79.

[16] Ibidunni, S., Osibanjo, O., Adeniji, A., Salau, O.P. and Falola, H. (2016). Talent Retention and Organizational Performance: A Competitive Positioning in Nigerian Banking Sector. Social and Management Sciences. 24(1): 1 - 13.

[17] Ihantola, E. and Kihn, L. (2011). Threats to Validity and Reliability in Mixed Methods Accounting Research. Qualitative Research in Accounting and Management. 8(1): 39 - 58.

[18] Imna, M. and Hassan, Z. (2015). Influence of Human Resource Management practices on Employee Retention in Maldives Retail Industry. International Journal of Accounting, Business and Management. 1(1): $1-28$.

[19] Kassa, T. (2015). Employee Motivation and its Effect on Employee Retention in Ambo Mineral Water Factory. International Journal of Advance Research in Computer Science and Management Studies. 3(3): $10-21$.

[20] Kaur, P. (2015). An Empirical Study on Factors Affecting Faculty Retention in Indian Business Schools. In: Chatterjee S., Singh N., Goyal D., Gupta N. (eds) Managing in Recovering Markets. Springer Proceedings in Business and Economics. Springer, New Delhi, INDIA. [https://link.springer.com/chapter /10.1007\%2F978-81-322-1979-8_5\#citeas] site visited on 22/12/2018.

[21] Kigo, S.K. and Gachunga, H. (2016). Effect of talent management strategies on employee retention in the insurance industy. The Strategic Journal of Management. 3(2): 977 - 1004.

[22] Kimberlin, C.L. and Winterstein, A.G. (2008). Validity and reliability of measurement instruments used in research. American Journal of Health-System Pharmacists. 65: 2276 - 2284. [http://www.ajhepworth. yolasite. com/resources/9817-Reliabillity\%20and\%20validity.pdf] site visited on 25/01/2017. 
The Influence of Training and Development on Employee Retention: Empirical Evidence from Banking Industry in Tanzania

[23] Kweka, N.A and Sedoyeka, E. (2014). Labor Turnover in Tanzania - Telecom vs Banking Sectors. International Journal of Computing and ICT Research. 8(2): 65 - 82.

[24] Lancaster, G. (2005). Research Methods: A Concise Introduction to Research in Managements and Business Consultancy. Butterworth-Heinemann. London.

[25] Ldama, J. and Bazza, M.I. (2015). Effect of training and development on employees' retention in selected banking institutions in Adamawa state-Nigeria. European journal of business and management. 7(36): 96 -101 .

[26] Mathimaran, B. and Kumar, A.A. (2017). Employee Retention Strategies - An Empirical Research. Global Journal of Management and Business Research: E Marketing. 17(1): 17 - 22.

[27] Mboya, W.J. (2012). Model for Determinants of Labour Mobility in the Banking Industry of Tanzania. The African Journal of Finance and Management. 21(2) [http://journal.ifm.ac.tz/index.Php/AJFM /article/view/51] site visited 22/06/2016.

[28] Mehrez, A. and Bakri, A. (2019). The impact of human resource practices on job satisfaction and intention to stay in emerging economies: Model development and empirical investigation among high caliber governmental employees in Qatar. Management Science Letters. 9 (2019): 425 - 442.

[29] Motlou, R.G. and Karodia, A.M. (2016). An evaluation of the impact of job satisfaction on employee retention at Lonmin Rowland Shaft North West province. Kuwait Chapter of Arabian Journal of Business and Management Review. 5(10): 15 - 49.

[30] Msengeti, D.M. and Obwogi, J. (2015). Effects of Pay and Work Environment on Employee Retention: A Study of Hotel Industry in Mombasa County. International Journal of Scientific and Research Publications. 5(4): $2250-3153$.

[31] Msisiri, P. R. and Juma, D. (2017). Relationship between non-financial rewards and retention of employees in banking industry: Case of Commercial Rural Development Bank-Arusha Tanzania. International Journal of Economics and Finance. 5(2): 1-38.

[32] Muhoho, J.M.E. (2014). Assessment of factors influencing employee retention in Tanzania's work organizations. International journal of innovation and applied studies. 9(2): 687 - 697.

[33] Mutiria, J.K., Rukangu, S. and Kubaison, K. (2015). Factors Influencing Employee Retention at Meru University of Science and Technology. IOSR Journal of Business and Management. 17(11): 75 - 82.

[34] Nasir, S.Z. and Mahmood, N. (2016). Determinants of Employee Retention: An Evidence from Pakistan. International Journal of Academic Research in Business and Social Sciences. 6(9): 182 - 194.

[35] Ngaira, P. and Oyagi, B. (2016).Analysis of Employee Retention Strategies on Organizational Performance of Hospitals in Mombasa County. International Journal of Business and Management Invention. 5(6): $40-45$.

[36] Nyambura, K.N. and Kamara, M. (2017). Influence of Career Development Practices on Employee Retention in Public Universities in Kenya A Case Of Technical University of Kenya. The Strategic Journal of Business \& Change Management. 4(2): 510 - 522.

[37] Øvretveit, J. (2011). Understanding the conditions for improvement: research to discover which context influences affect improvement success. BMJ Quality Safety. 20(1): 18 - 23.

[38] Oyagi, N.B. and Kembu, S.A. (2014).To assess the relationship between motivation and retention of academic staff in selected public higher institutions of learning in Dar es-Salaam. International journal of advancement in engineering technology, management and applied science. 1(4):54 - 61 .

[39] Palwasha, B., Faizuniah, P., Johanim, J. and Ashfaq, A. (2017). The Impact of Compensation and Promotional Opportunities on Employee Retention in Academic Institutions: The Moderating Role of Work Environment. International Journal of Economic Perspectives. 11(1): 378 - 391.

[40] Rakhra, H.K. (2018). Study on factors influencing employee retention in companies. International Journal of Public Sector Performance Management. 4(1): 57 - 79.

[41] Rashidi, A.A. and Rahman, M. (2013). Retention Issues in Banking Industry of Pakistan: A Case Study of Habib Metro and Soneri Bank. 11(1):57 - 66.

[42] Regina, C. Dy. and Rosalia, T.C. (2015). A Strategic Employee Retention Model Based on Employee Perception. European Journal of Business Management. 2 (5), 25-35.

[43] Salman, A., Ahmad, N. and Matin, F. (2014). Factors Affecting on Employees Retention in Banking Sector: An Investigation from Karachi. European Journal of Business and Management. 6(37): 169 - 178.

[44] Samuel, M.O. and Chipunza, C. (2009). Employee retention and turnover: Using motivational variables as a panacea. African Journal of Business Management. 3(8): 410 - 415.

[45] Shahin, N. (2017). A Study of Employee Retention in the Pharmaceuticals Sector in Ranchi City. International Journal of Engineering Technology Science and Research. 4(9): 292 - 301. 
[46] Sohail, N., Muneer, A., Tanveer, Y and Tariq, H. (2011). Loosing your best talent: employee retention the dilemma of Textile Industry. A case of textile sector. Interdisciplinary journal of contemporary research in business. 3(8): 897 - 903.

[47] Streiner, D.L. (2003). Statistical Developments and Applications, Starting at the Beginning: An Introduction to Coefficient Alpha and Internal Consistency. Journal of Personality Assessment. 80(1): 99 103.

[48] Terera, S.R. and Ngirande, H. (2014). The Impact of Training on Employee Job Satisfaction and Retention among Administrative Staff Members: A Case of a Selected Tertiary Institution. Journal of Social Science. 39(1): $43-50$.

[49] Thirupathy, A. and Dhayalan, C. (2016). Employee retention and turnover using motivational variables at India. International Journal of Research. 4(8): 1 - 9.

[50] Umamaheswari, S. and Krishnan, J. (2016).Work Force Retention: Role of Work Environment, Organization Commitment, Supervisor Support and Training \&Development in Ceramic Sanitary Ware Industries in India. Journal of Industrial Engineering and Management. 9(3):612 - 633.

[51] Waweru, S.W. and Kagiri, A. (2018). Effect of Human Resource Management Strategies on Employee Retention: A Survey of Agriculture sector Ngo's based in Nairobi, Kenya. The Strategic Journal of Business \& Change Management. 5(2): 2340 - 2360.

[52] Westen, D. and Rosenthal, R. (2003). Quantifying Construct Validity: Two Simple Measures. Journal of Personality and Social Psychology. 84(3): 608 - 618.

[53] Zareen, M., Razzaq, K. and Ramzan, M. (2013). Impact of employee retention on performance: the moderating role of employee psychological perception towards retention plan. Interdisciplinary journal of contemporary research in business. 4(10): 822 - 830.

Citation: William Amos Pallangyo, Amos Ephraim Hanai. "The Influence of Training and Development on Employee Retention: Empirical Evidence from Banking Industry in Tanzania” International Journal of Political Science (IJPS), vol 6, no.1, 2020, pp. 22-32. doi: http://dx.doi.org/10. 20431/2454-9452.0601003.

Copyright: (C) 2020 Authors. This is an open-access article distributed under the terms of the Creative Commons Attribution License, which permits unrestricted use, distribution, and reproduction in any medium, provided the original author and source are credited. 